Dominika Kordela

Uniwersytet Szczeciński

\title{
Przedsiębiorstwa rodzinne na rynku papierów wartościowych - doświadczenia z rynku niemieckiego
}

\section{FAMILY ENTERPRISES ON THE SECURITIES MARKET - EXPERIENCE FROM GERMANY}

\begin{abstract}
$W$ artykule podjęto problematykę zwiazanq z giełdowymi przedsiębiorstwami rodzinnymi. Autorka prezentuje znaczenie przedsiębiorstw rodzinnych $w$ gospodarce Niemiec oraz ocene wykorzystania przez niemieckie przedsiębiorstwa rodzinne finansowania udziałowego. Celem artykutu jest przedstawienie przesłanek skłaniajacych niemieckie przedsiębiorstwa rodzinne do debiutu gietdowego oraz charakterystyka giełdowych przedsiębiorstw rodzinnych $w$ Niemczech. Ze względu na przegladowy charakter artykułu, głównq metoda badawczq wykorzystanq dla realizacji celu jest krytyczna analiza zagranicznej $i$ polskiej literatury przedmiotu, na postawie której zaprezentowano wyniki najistotniejszych badań niemieckich przedsiębiorstw rodzinnych. Wykorzystano również elementy statystyki opisowej oraz metode opisowa. Przedstawione analizy $i$ oceny wskazuja, że przedsiębiorstwa rodzinne $w$ Niemczech majq znaczqcy wplyw na gospodarke realnq, jak również sq istotne dla giełdy papierów wartościowych, co wyrażone jest m.in.: liczbq debiutów gietdowych oraz liczbq notowanych firm rodzinnych. W porównaniu do nierodzinnych przedsiębiorstw obecnych na gietdzie charakteryzujq się niższa sumq bilansowa $i$ niższymi obrotami. Natomiast ocena korzyści zwiqzanych z obecnościq na giełdzie zależna jest m.in. od wielkości przedsiębiorstwa.
\end{abstract}

Słowa kluczowe: przedsiębiorstwa rodzinne, rynek papierów wartościowych, finansowanie przedsiębiorstw.

\section{Wstęp}

W gospodarce niemieckiej przedsiębiorstwa rodzinne odgrywają bardzo ważną rolę, stanowią bowiem 91\% wszystkich aktywnych przedsiębiorstw i tworzą 57\% miejsc pracy $\mathrm{w}$ sektorze prywatnym ${ }^{1}$. Wiele $\mathrm{z}$ nich to podmioty działające na rynku międzynarodowym, np. Schwarz-Gruppe, Robert Bosch GmBH czy Metro-Konzern. Biorąc pod uwage skalę działania, liczbę zatrudnionych osób, wartość obrotów czy poziom aktywności na rynku międzynarodowym bardziej ciążą ku wielkim koncernom niż ku stereotypowemu wyobrażeniu firmy rodzinnej. Przedsiębiorstwa rodzinne podejmując decyzje o debiucie giełdowym przechodzą $\mathrm{z}$ modelu kontroli (charakteryzującego się dużym poziomem aktywności właścicieli i relatywnie niewielką

${ }^{1}$ Die Volkswirtchaftliche Bedeutung der Familienunternehmen, Stiftung Familienunternehmen, Monachium 2017, s.2. 
liczbą właścicieli) do modelu rynkowego (oznacza to spadek aktywności właścicieli i wzrost ich liczby) $)^{2}$, co wpływa na zmianę ich funkcjonowania i perspektywy rozwoju.

Głównym celem artykułu jest przedstawienie przesłanek skłaniających niemieckie przedsiębiorstwa rodzinne do debiutu giełdowego oraz charakterystyka giełdowych przedsiębiorstw rodzinnych w Niemczech. Artykuł ma charakter przeglądowy, uznając, że „podstawowy kanon nauki nawiązuje do ciagłości”, autorka podejmuje się badań literaturowych, które mają posłużyć jako podstawa do prowadzenia dalszych badań w tym obszarze. W związku $\mathrm{z}$ powyższym przygotowując artykuł, wykorzystano następujące metody badawcze: krytyczną analizę zagranicznej i polskiej literatury przedmiotu, analizy statystyczne $\mathrm{z}$ wykorzystaniem statystyki opisowej obejmujące ocenę danych ze źródeł wtórnych oraz metodę opisową. W metodyce przeprowadzonych badan literaturowych kluczowe znaczenie miała zagraniczna kwerenda biblioteczna. Autorka pozyskała niemieckojęzyczne książi i artykuły naukowe dotyczące tematyki firm rodzinnych (w tym szczególnie giełdowych firm rodzinnych). Przeanalizowano również raporty instytucji i instytutów badających tę grupę podmiotów gospodarczych w Niemczech. Kolejnym etapem była analiza znaczącego wkładu -w postaci publikacji zwartych i artykułów naukowych - polskich naukowców w badania nad funkcjonowaniem i finansowaniem firm rodzinnymi. Ze względu na objętość artykułu nie wszystkie źródła literaturowe mogły znaleźć odniesienie w publikacji. W wyniku przeglądu literatury uznano, że na gruncie polskim - wciąż - istnieje luka poznawcza w zakresie wykorzystania przez przedsiębiorstwa rodzinne finansowania udziałowego na rynku kapitałowym ${ }^{4}$.

W artykule autorka wychodzi od definicyjnych ujęć przedsiębiorstwa rodzinnego i giełdowego przedsiębiorstwa rodzinnego, następnie prezentuje znaczenie przedsiębiorstw rodzinnych w Niemczech dla gospodarki realnej. W kolejnych częściach opisano teoretyczne aspekty związane $\mathrm{z}$ finansowaniem przedsiębiorstw rodzinnych oraz przedstawiono wyniki wybranych badan przeprowadzonych wśród giełdowych przedsiębiorstw rodzinnych w Niemczech.

\section{Giełdowe przedsiębiorstwo rodzinne - kwestie definicyjne}

W literaturze przedmiotu nie wskazano jednej ogólnie przyjętej definicji przedsiębiorstwa rodzinnego między innymi z powodu interdyscyplinarności tematyki i co z tym związane dużej liczby dyscyplin naukowych zaangażowanych w badanie tych podmiotów $^{5}$, a także ze względu na ich zróżnicowanie ${ }^{6}$. Na brak jednoznacznej, powszechnie uznawanej definicji przedsiębiorstwa rodzinnego oraz mnogość podejść

\footnotetext{
${ }^{2}$ M. Stradomski, Finansowanie obce firm rodzinnych na rynku niedoskonatym, Polskie Wydawnictwo Ekonomiczne, Warszawa 2010, s.165.

${ }^{3}$ W. Czakon, Metodyka systematycznego przegladu literatury, Przegląd Organizacji nr 3/2011, s.57.

${ }^{4}$ Przykładem pracy podejmującej tę problematykę jest pozycja W. Popczyk, Przedsiębiorstwo rodzinne $w$ otoczeniu globalnym. Analiza porównawcza ekspansji międzynarodowej firm rodzinnych i nierodzinnych z rynku NewConnect, Wydawnictwo Uniwersytetu Łódzkiego. Łódź 2013.

${ }^{5}$ E. Niedbała, Firmy rodzinne - obiekt badawczy, MBA nr 5/2002, s. 44.

${ }^{6}$ H. Pernsteiner H, J.Węcławski (red.), Finansowanie i corporate governance $w$ przedsiębiorstwach rodzinnych, C.H. Beck, Warszawa 2016, s. 21.
} 
i koncepcji definicyjnych wskazują między innymi Klein ${ }^{7}$, Safin $^{8}$, Stradomski ${ }^{9}$, Małyszek $^{10}$. Definiowanie przedsiębiorstwa rodzinnego dokonywane jest zarówno w oparciu o metody deskryptywne, jak i metody ilościowe. Podejmowano w badaniach próby określenia wartości progowych dla kryteriów mierzalnych określających wpływ rodzinny na przedsiębiorstwo, tworząc mierniki ilościowe uzasadniające nazwanie podmiotu gospodarczego przedsiębiorstwem rodzinnym ${ }^{11}$.

W polskiej literaturze przedmiotu badane były różne aspekty działalności firm rodzinnych, analizie poddawano obszary związane $\mathrm{z}$ zarządzaniem strategicznym, zarządzaniem kapitałem ludzkim, funkcjonowaniem firm rodzinnych w gospodarce rynkowej, a także $\mathrm{z}$ finansowanie firm rodzinnych ${ }^{12}$. Biorąc pod uwagę cechy charakteryzujące przedsiębiorstwo rodzinne Marjański wskazuje, że istotnym czynnikiem wyróżniających przedsiębiorstw rodzinne $\mathrm{z}$ ogółu podmiotów gospodarczych jest sukcesja ${ }^{13}$. Podobieństwa podejścia można doszukać się w proponowanym przez Więcek-Jankę, i Lewandowską modelu pięciu poziomów definicyjnych firmy rodzinnej ${ }^{14}$ :

- Poziom 1 - Wielopokoleniowa firma rodzinna - jest to najwęższy zakres definicyjny, obejmujący firmy rodzinne, w których już miała miejsce sukcesja.

- Poziom 2 - Firma rodzinna u progu sukcesji - to firma, w zarządzanie którą zaangażowane są co najmniej dwie osoby z rodziny i planowana jest sukcesja.

- Poziom 3 - Jednopokoleniowa firma rodzinna - rodzina (co najmniej jedna osoba) na wpływ na podejmowanie decyzji, większość głosów w organach decyzyjnych jest $\mathrm{w}$ posiadaniu rodziny, przynajmniej jeden przedstawiciel rodziny bierze udział w zarządzaniu spółką, a w przypadku spółek notowanych na giełdzie warunkiem jest założenie firmy przez rodzinę lub nabycie przez nią udziałów lub posiadanie przez potomków rodziny co najmniej $25 \%$ głosów.

- Poziom 4 - Przedsiębiorstwa z tożsamością rodzinną - czyli takie które postrzegają się w kategoriach firmy rodzinnej.

\footnotetext{
${ }^{7}$ S. Klein, Familienunternehmen. Teoretische und empirische Grundlagen, Josef Eul Verlag, Lohmar-Köln 2010, 3-6.

${ }^{8}$ K. Safin, Przedsiębiorstwo rodzinne, Wydawnictwo Akademii Ekonomicznej im. Oskara Langego we Wrocławiu, Wrocław 2007, s. 46-56.

${ }^{9}$ M. Stradomski, op.cit., s. 41-48.

${ }^{10}$ E. Małyszek, Problem różnorodności definicji i typologii firm rodzinnych - konsekwencje i podejścia do jego rozwiqzania, [w:] Sułkowski Ł. (red.), Firmy rodzinne - wspótczesne wyzwania przedsiębiorczości rodzinnej. Kierunki i strategie rozwoju. Przedsiębiorczość i Zarządzanie, Tom XIII, Zeszyt 7. Łódź 2012.

${ }^{11}$ K. Safin, op. cit. s. 37-45, M. Stradomski, op.cit., s.41-48.

${ }^{12}$ M.in., np.: Stradomski M., op.cit.; Winnicka-Popyczyk A., Finansowanie innowacji w polskich firmach rodzinnych, Wydawnictwo Uniwersytetu Łódzkiego, Łódź 2016; Zajkowski R, Transfer wiedzy, własności $i$ wartości w przedsiębiorstwach rodzinnych. Efekt drugiego pokolenia, Wydawnictwo C.H. Beck, Warszawa 2018.

${ }^{13}$ A. Marjański, Sukcesja jako wyróżnik przedsiębiorstwa rodzinnego, [w:] Sułkowski Ł. (red.), Firmy rodzinne - wspótczesne wyzwania przedsiębiorczości rodzinnej. Kierunki i strategie rozwoju. Przedsiębiorczość i Zarządzanie, Tom XIII, Zeszyt 7. Łódź 2012.

${ }^{14}$ E. Więcek-Janka, A. Lewandowska, Model pięciu poziomów definiowania firm rodzinnych[w:] Sułkowski Ł., Marjański A. (red.), Firmy rodzinne - rozwój teorii i praktyki zarzqdzania, Przedsiębiorczość i Zarządzanie, Tom XVIII, Zeszyt 6, część II, Wydawnictwo Społecznej Akademii Nauk, Łódź-Warszawa 2017 , s. $165-166$.
} 
- Poziom 5 - Przedsiębiorstwa potencjalnie rodzinne - na tym poziomie uwzględniono kryterium własności firmy tj. 50\% udziałów należy do osoby prywatnej lub rodziny.

Ogólnie i zgodnie $\mathrm{z}$ powszechnym poglądem można przyjąć jak wskazują Pernsteiner i Węclawski ${ }^{15}$, że przedsiębiorstwo rodzinne to podmiot gospodarczy znajdujący się we władaniu rodziny. Jednak przegląd literatury i dostępnych wyników badań dowodzi, że „władanie rodziny” to termin szeroki i niedoprecyzowany. Władanie może być określane przy użyciu wielu kryteriów, warunków i mierników. Pomimo różnorodności definicji autorzy badań są zgodni, że w procesie klasyfikacji podmiotów gospodarczych do grona firm rodzinnych decydujące znaczenie mają następujące kryteria: udział rodziny w kapitale własnym przedsiębiorstwa (własność), reprezentacja rodziny w zarządzie (wpływ na funkcjonowanie i zarządzanie) oraz radzie nadzorczej (udział w organach kontrolnych). Dyskusyjne jest natomiast uszczegółowienie skali oddziaływania przez rodzinę na przedsiębiorstwo w oparciu o wymienione kryteria.

$\mathrm{Na}$ przykład Institut für Mittelstandsforschung (IfM) w Bonn przedstawia następującą definicję: przedsiębiorstwo rodzinne to podmiot gospodarczy, w którym funkcje własności i zarządzania jednocześnie sprawuje właściciel lub rodzina. Jednak zgodnie z przyjętymi przez IfM założeniami każdy podmiot gospodarczy spełnia kryteria definicyjne przedsiębiorstwa rodzinnego, jeżeli: maksymalnie dwie osoby fizyczne lub członkowie ich rodziny posiadają co najmniej 50\% udziałów przedsiębiorstwa i członek bądź członkowie rodziny pełnią funkcje w zarządzie ${ }^{16}$.

Z kolei Stiftung Familienunternehmen proponuje szersze ujęcie i definicją przedsiębiorstwo rodzinne obejmuje dwa rodzaje przedsiębiorstw, rozróżniając:

- Przedsiębiorstwa kontrolowane przez rodzinę (Familienkontrollierte Unternehmen) - czyli te, które są kontrolowane przez osoby fizyczne (spełnione jest kryterium własności), natomiast warunkiem koniecznym nie jest pełnienie funkcji przez członków rodziny $\mathrm{w}$ zarządzie $\mathrm{i}$ radzie nadzorczej przedsiębiorstwa ${ }^{17}$.

- Przedsiębiorstwo prowadzone przez wlaściciela (Eigentümergeführte Familienunternehmen) - do tej grupy zalicza się przedsiębiorstwa kontrolowane przez osobę lub osoby fizyczne z rodziny (kryterium własności), dodatkowym kryterium jest wymóg sprawowania przez co najmniej jednego z właścicieli funkcji w zarządzie.

Ponadto zgodnie z kryteriami przyjętymi przez Stiftung Familienunternehmen dowolne przedsiębiorstwo można zdefiniować jako rodzinne jeżeli spełnione są poniższe trzy warunki $i^{18}$ :

- większość praw głosu posiada osoba fizyczna (osoby fizyczne), która to przedsiębiorstwo założyła; osoba fizyczna, która kupiła udziały w przedsiębiorstwie lub małżonkowie, rodzice, dzieci lub ich spadkobiercy,

- większość praw głosu wykonywana jest bezpośrednio lub pośrednio,

\footnotetext{
${ }^{15}$ H. Pernsteiner, J. Węcławski, op.cit. s.21.

${ }^{16}$ www.ifm-bonn.org, data dostępu 30.06.2018.

17 Wskazać należy, że takie podejście do definiowania podmiotów gospodarczych jako przedsiębiorstw rodzinnych jest najczęściej używany zarówno powszechnie w Niemczech, jak i w niemieckiej literaturze przedmiotu.

${ }^{18}$ www.familienunternehmen.de, data dostępu 30.06.2018.
} 
- co najmniej jeden przedstawiciel rodziny zasiada w zarządzie lub radzie nadzorczej.

Próby definiowania przedsiębiorstw rodzinnych podjęli również Eksperci Komisji Europejskiej. W opracowanym przez nich raporcie Overview of Family Business Relevant Issues: Research, Networks, Policy Measures and Existing Studies z 2009 wskazali na kryteria kwalifikujące podmioty gospodarcze do grupy przedsiębiorstw rodzinnych, odnosząc się również do klasyfikacji giełdowych przedsiębiorstw rodzinnych $^{19}$. Konkluzje raportu są następujące:

- Podmiot gospodarczy można uznać za przedsiębiorstwo rodzinne jeżeli: a) większość praw do podejmowania decyzji mają osoby fizyczne będące założycielami przedsiębiorstwa bądź spadkobiercami założycieli; b) większość praw do podejmowania decyzji ma charakter pośredni lub bezpośredni; c) co najmniej jeden przedstawiciel rodziny lub krewnych formalnie uczestniczy w zarządzaniu przedsiębiorstwem.

- Przedsiębiorstwo notowane na giełdzie spełnia definicję przedsiębiorstwa rodzinnego jeżeli osoba fizyczna, która to przedsiębiorstwo założyła bądź odziedziczyła, lub członkowie jej rodziny i sukcesorzy posiadają łącznie ponad $25 \%$ głosów uprawniających do podejmowania decyzji.

Szersze kryteria do określenie giełdowych przedsiębiorstw rodzinnych przyjmuje Frankfurter Wertpapierbörse. Stosowana systematyka wyrażona jest w konstrukcji indeksów firm rodzinnych (DAXplus Family, DAXplus Family 30), w których ujmowane są przedsiębiorstwa spełniające następujące warunki ${ }^{20}$.

- rodzina założyciela/założycieli przedsiębiorstwa posiada co najmniej $25 \%$ praw głosu; lub

- $\quad$ rodzina zasiada w zarządzie bądź radzie nadzorczej przedsiębiorstwa i posiada co najmniej $5 \%$ praw głosów.

$\mathrm{Z}$ przedstawionych $\mathrm{w}$ literaturze przedmiotu koncepcji ilościowego podejścia do definiowania przedsiębiorstwa rodzinnego warte uwagi są miernik rodzinności opracowanego przez Klein czy koncepcja von Schuttenbacha ${ }^{21}$. Niewatpliwą zaletą mierników jest ich przejrzystość i przydatność podczas kwalifikowania podmiotów gospodarczych do badań. Jednak wskazuje się również na wady np.: pominięcie kultury organizacyjnej przedsiębiorstwa będącej odzwierciedleniem kultury rodzinnej ${ }^{22}$.

$\mathrm{Na}$ istotną cechę przedsiębiorstw rodzinnych - z punktu widzenia ich obecności i aktywności na rynku papierów wartościowych - wskazuje Stradomski ${ }^{23}$. W przedsiębiorstwie rodzinnym mianowicie przez większą część cyklu jego życia jest jeden ten sam podmiot dominujący, czyli rodzina. Dlatego przedsiębiorstwa rodzinne są szczególnym przykładem podmiotów gospodarczych, których cechą jest skupiony charakter własności -inwestorem dominującym jest rodzina. Ma to swoje implikacje, chociażby duża koncentracja akcjonariatu wpływa na gorsze warunki oferty pierwotnej

\footnotetext{
${ }^{19}$ H. Pernsteiner, J. Węcławski, op.cit., s. 25.

${ }^{20}$ www.dax-indices.com, data dostępu 30.06.2018.

${ }^{21}$ K. Safin, op. cit., s. 47-57.

${ }^{22}$ J. Niemczyk, P. Kotliński, WIG Rodzinny na Giełdzie Papierów Wartościowych w Warszawie, [w:] Sułkowski Ł., (red.), Firmy rodzinne - determinanty funkcjonowania i rozwoju. Współczesne aspekty zarządzania, Przedsiębiorczość i Zarządzanie, Tom XII, Zeszyt 6, Łódź, s. 312.

${ }^{23}$ M. Stradomski, op.cit., s. 124 .
} 
(oznacza wyższe dyskonto), które jednak jest akceptowane przez właścicieli (rodzinę) $\mathrm{z}$ powodu potrzeby dywersyfikacji struktury własnościowej ${ }^{24}$.

\section{Charakterystyka i znaczenie przedsiębiorstw rodzinnych w Niemczech}

Jedne $\mathrm{z}$ najbardziej kompleksowych badań niemieckich przedsiębiorstw rodzinnych zostały przeprowadzone przez S. Klein w roku 1995, wartość tych wyników jest tym większa, że zostały one powtórzone i poszerzone w roku 2000 - stąd ich duża wartość poznawcza. Klein ${ }^{25}$ wskazuje, że w Niemczech od zawsze przedsiębiorstwa rodzinne były silne i bardzo aktywne, a ich udział w ogólnej liczbie podmiotów gospodarczych był znaczący. Cechą charakterystyczną przedsiębiorstw rodzinnych w Niemczech jest ich długoletnia, nawet ponad stuletnia historia. Według badań Klein ${ }^{26}$ prawie 8600 działających w roku 1996 przedsiębiorstw (ponad 3\%) to przedsiębiorstwa powstałe przed rokiem $1871^{27}$, z czego aż $74,5 \%$ stanowiły przedsiębiorstwa rodzinne. Według danych Stiftung Familienunternehmen w roku 2017 średni wiek niemieckich przedsiębiorstw rodzinnych ujętych w zestawieniu TOP $500^{28}$ wynosi 101,8 lat, co więcej połowa przedsiębiorstw została założona przed 1923 rokiem. Długoletnia historia $\mathrm{i}$ aktywność tych podmiotów gospodarczych działających wciąż w formie firm rodzinnych zadaje się potwierdzać ich cechę t.j. nastawienie na długoterminową perspektywę działania, która z kolei determinuje dobór źródeł finansowania tak, że preferowane są własne (rodzinne) środki finansowe, a dopiero po ich wykorzystaniu pozyskiwane są źródła zewnętrzne ${ }^{29}$.

Tabela 1. Znaczenie gospodarcze przedsiębiorstw kontrolowanych przez rodzinę ${ }^{30} \mathrm{w}$ Niemczech.

\begin{tabular}{l|r|r|}
\cline { 2 - 3 } \multicolumn{1}{c|}{} & \multicolumn{1}{|c|}{ Przedsiębiorstwa ogółem } & z tego przedsiębiorstwa rodzinne \\
\hline Liczba w tys. & 2697 & 2427 \\
\hline Obrót w mld euro & 5927 & 2891 \\
\hline Liczba zatrudnionych w mln & 29,5 & 15,6 \\
\hline
\end{tabular}

Źródło: Die Volkswirtchaftliche Bedeutung der Familienunternehmen, Stiftung Familienunternehmen, München 2017.

Stwierdzenie o dużym znaczeniu przedsiębiorstw rodzinnych $\mathrm{w}$ gospodarce Niemiec znajduje potwierdzenie $\mathrm{w}$ danych liczbowych, przedsiębiorstwa kontrolowane przez rodzinę stanowiły w roku 2015 90\% wszystkich aktywnych podmiotów gospodarczych $(91 \%$ jeżeli wyłączy się z liczby przedsiębiorstw te o charakterze publicznym), wypracowują blisko $49 \%$ obrotu w gospodarce i tworzą prawie $52 \%$

\footnotetext{
${ }^{24}$ Ibidem, s. 166.

${ }^{25}$ S. Klein, op.cit., s. 21.

${ }^{26}$ Ibidem, s.32 -33 .

${ }^{27}$ Data Zjednoczenia Niemiec.

${ }^{28}$ Zestawienie prezentuje 500 największych firm rodzinnych w Niemczech.

${ }^{29}$ J. Niemczyk, P. Kotliński, op.cit., s.307-308.

${ }^{30}$ Zgodnie z ujęciem definicyjnym Stiftung Familenunternehmen dane dotyczą przedsiębiorstw kontrolowanych przez rodzinę (a nie przedsiębiorstw prowadzonych przez właściciela).
} 
wszystkich miejsc pracy (57\% przy uwzględnianiu tylko prywatnych przedsiębiorstw) $)^{31}$. Przedsiębiorstwa rodzinne i kontrolowane przez rodziny tworzą ponad $40 \% \mathrm{PKB}^{32}$. Dane dotyczące liczby przedsiębiorstw rodzinnych, obrotu przez nie wypracowanego oraz liczby zatrudnionych osób (tabela 1) potwierdzają ich istotne znaczenie w gospodarce.

Według danych statystycznych największy odsetek przedsiębiorstw rodzinnych jest w grupie mikro i małych przedsiębiorstw, wraz ze wzrostem liczby zatrudnionych maleje odsetek firm rodzinnych w danej grupie wielkości przedsiębiorstw (rysunek 1).

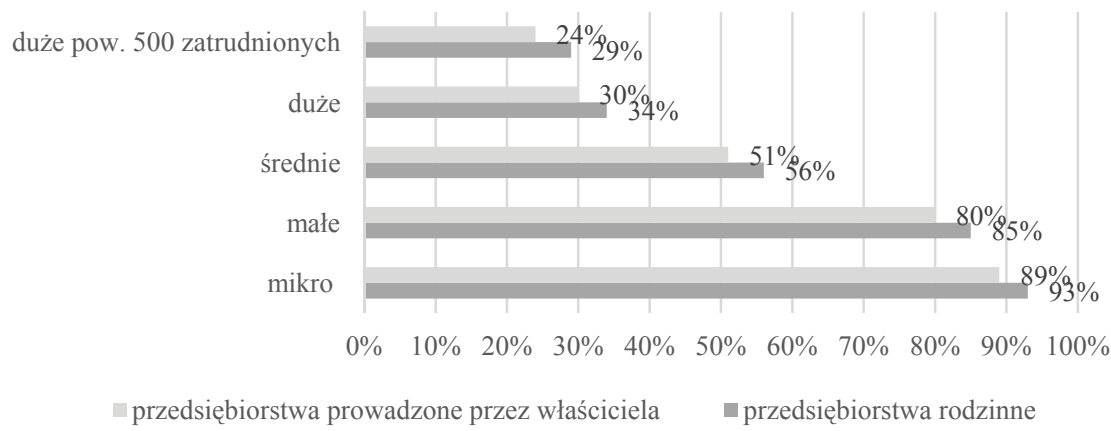

Rysunek 1. Udział przedsiębiorstw rodzinnych w poszczególnych grupach wielkościowych podmiotów gospodarczych (według liczby zatrudnionych osób) w Niemczech

Źródło: Die Volkswirtchaftliche Bedeutung der Familienunternehmen, Stiftung Familienunternehmen, Monachium 2017.

Również według kryterium wartości obrotu przedsiębiorstwa rodzinne dominują wśród mikroprzedsiębiorstw (ponad 90\%), i stanowią ponad 80\% małych przedsiębiorstw (rysunek 2).

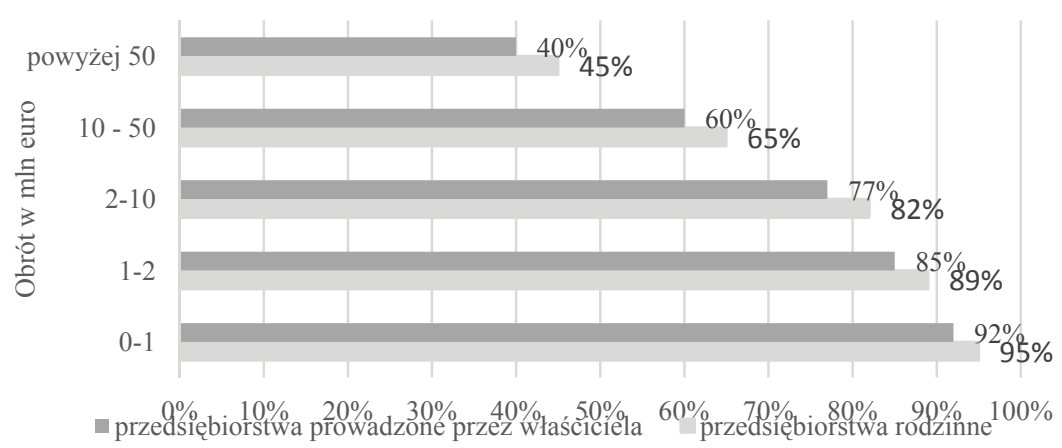

Rysunek 2. Udział przedsiębiorstw rodzinnych w poszczególnych grupach wielkości wg kryterium obrotu Źródło: Die Volkswirtchaftliche Bedeutung der Familienunternehmen, Stiftung Familienunternehmen, Monachium 2017.

${ }^{31}$ Die Volkswirtchaftliche Bedeutung der Familienunternehmen, Stiftung Familienunternehmen, Monachium 2017, s. 2.

${ }^{32}$ S. Gottschalk i in. , Die volkswirtschaftliche Bedeutung der Familienunternehmen, Stiftung

Familienunternehmen, Monachium.2014, s.19-21. 
Badania dotyczące form organizacyjno-prawnych przedsiębiorstw rodzinnych wskazuja, że $85 \%$ spółek osobowych i $79 \%$ spółek kapitałowych to przedsiębiorstwa rodzinne ${ }^{33}$.

Z punktu widzenia niemieckich przedsiębiorstw rodzinnych najważniejszymi źródłami finansowania są pożyczki i kredyty (blisko 80\% wskazań), a w następnej kolejności (ponad 20\% wskazań) instrumenty dłużne (obligacje i krótkoterminowe papiery dłużne), faktoring, blisko $20 \%$ wskazuje kredyty konsorcjalne, a ponad $20 \%$ firm rodzinnych wykorzystuje finansowanie udziałowe ${ }^{34}$.

\section{Finansowanie przedsiębiorstw rodzinnych - wybrane aspekty}

Finansowanie przedsiębiorstw rodzinnych jest zdeterminowane takim doborem źródeł i instrumentów finansowania, który zabezpieczy przed ryzykiem upadłości lub przejęciem przedsiębiorstwa oraz umożliwi przekazanie przedsiębiorstwa w dobrej kondycji ekonomicznej następnym pokoleniom. Wybór źródeł i instrumentów zależy również od wypływu określonego kapitału na niezależność ekonomiczną przedsiębiorstwa ${ }^{35}$.

Gallo, Tapies i Cappuyns ${ }^{36}$ wskazują, że przedsiębiorstwa rodzinne kierują się szczególną logiką finansowania. Mianowicie decyzje finansowe podejmowane w tych podmiotach gospodarczych nie są oparte wyłącznie na maksymalizacji wartości, lecz uwzględniają również inne czynniki na przykład zgodność sposobu prowadzenia firmy z pewną tradycją czy możliwość zaoferowania pracy członkom rodziny.

Literatura przedmiotu wskazuje, że przedsiębiorstwa rodzinne generalnie preferują konserwatywną strategię finansowania i wewnętrzne źródła finansowania, co wyraża się też $\mathrm{w}$ wysokim poziomie kapitału własnego ${ }^{37}$. Tę grupę przedsiębiorstw charakteryzuje również wysoki poziom finansowania z zatrzymanego zysku, co związane jest z dużą skłonnością do rezygnacji $\mathrm{z}$ wypłat dywidendy ${ }^{38}$. W konsekwencji przedsiębiorstwa rodzinne charakteryzują się niższymi od średnich wskaźnikami zadłużenia, co również potwierdzają liczne badania ${ }^{39}$. Kapitał udziałowy, z kolei, ze względu na oczekiwany przez inwestorów udział w zyskach pozyskiwany ma relatywnie wysoki koszt ${ }^{40}$.

Stradomski ${ }^{41}$ wskazuje ponadto, że po debiucie giełdowym firmy rodzinnej istotne są relacje właścicieli skupionych wokół rodziny $\mathrm{z}$ inwestorami mniejszościowymi. Sposobem na ochronę dominującej pozycji rodziny w przedsiębiorstwie może być debiut giełdowy oparty na strategii pozyskania drobnych inwestorów. $\mathrm{Z}$ jednej strony pozwala

\footnotetext{
${ }^{33}$ Die Volkswirtchaftliche Bedeutung der Familienunternehmen, Stiftung Familienunternehmen, Monachium 2017, s. 19.

${ }^{34}$ A.K.Achleitner, C. Kaserer, N. Günther, S. Volk, Die Kapitalmarktfähigkeit von Familienunternehmen, Unternehmensfinanzierung über Schuldschein, Anleihe und Börsengang, Stiftung Familienunternehmen, Monachium 2011, s.169.

${ }^{35}$ H. Pernsteiner, J.Węcławski, op.cit., s.54.

${ }^{36}$ M.A. Gallo, J. Tapies, K. Cappuyns, Comparison of family and nonfamily business: Financial logic and personal preferences, Family Business Review, nr 17(4) 2004, s. 303-318.

${ }^{37}$ A.K. Achleitner in, op.cit. 2011, s.42; H. Pernsteiner, J. Węcławski, op.cit., s.54-55; MA. Gallo, A. Vilaseca, Finance in family business, Family Business Review, tom 9, Wiley Online Library, 1996, s. 387-401.

${ }^{38}$ H. Pernsteiner, J. Węcławski, op.cit. , s.54-55, 73.

${ }^{39}$ szerzej M. Stradomski, op.cit., s.186-187.

${ }^{40}$ Ibidem, s. 165.

${ }^{41}$ Ibidem, s. 131.
} 
na pozyskanie kapitału udziałowego, a z drugiej zachowany zostaje dominujący wpływ rodziny na decyzje $\mathrm{w}$ przedsiębiorstwie ${ }^{42}$. Jednakże nawet $\mathrm{w}$ przypadku notowania przedsiębiorstwa rodzinnego na giełdzie papierów wartościowych dopływ nowego kapitału może być ograniczony z powodu dążenia właścicieli do utrzymania dominującej pozycji w strukturze kapitału i utrzymania liczby praw głosu, co może spowodować mniejsze zainteresowanie inwestorów ${ }^{43}$.

Decyzja o IPO w przedsiębiorstwach rodzinnych jest elementem strategii finansowania i skutkuje zarówno korzyściami dla rozwoju przedsiębiorstwa (m.in.: łatwiejszy dostęp do kapitału, zwiększenie wartości firmy, podwyższenie jej prestiżu), jednak też tworzy szereg zagrożeń (utrata cechy prywatności firmy, ograniczenie siły rodziny, presja ze strony nowych akcjonariuszy) ${ }^{44}$.

\section{Niemieckie firmy rodzinne na giełdzie - wyniki wybranych badań}

W podjęciu decyzji o pozyskaniu kapitału udziałowego poprzez IPO kluczowym czynnikiem może być planowany rozwój przedsiębiorstwa, zwłaszcza że często wewnętrzne źródła finansowania nie są wystarczające w kontekście finansowania rozwoju ${ }^{45}$.

Kompleksowe badania dotyczące obecności przedsiębiorstw rodzinnych na giełdzie papierów wartościowych zostały przeprowadzone przez zespoły pod kierownictwem A.K. Achleitner. Wyniki wskazują, że na decyzje niemieckich przedsiębiorstw rodzinnych o publicznej emisji papierów wartościowych wpływ mają zarówno czynniki zewnętrzne $^{46}$ :

- zaostrzenie polityki kredytowej przez banki,

- zmiana warunków udzielania kredytów,

jak również wewnętrzne:

- dążenie do szybszego rozwoju i wzrostu,

- chęć zmiany struktury kapitałowej (restrukturyzacja),

- planowana sprzedaż przedsiębiorstwa i wyjście z inwestycji,

- dywersyfikacja źródeł finansowania (często rozumiana jako uniezależnienie się od banków)

Wskazuje się również, że w niemieckich przedsiębiorstwach rodzinnych gotowość do skorzystania z finansowania na rynku kapitałowych często zależy nie od otwartości rodziny na nowe źródła finansowania, ale od wiedzy z zakresu finansów i rynku kapitałowego oraz doświadczania członków rodziny czy też chęci skorzystania z usług doświadczonych doradców ${ }^{47}$.

\footnotetext{
${ }^{42}$ T.R. Smus, Strategie finansowe firm rodzinnych, [w:] Sułkowski Ł., (red.), Firmy rodzinne - determinanty funkcjonowania i rozwoju. Wspótczesne aspekty zarzqdzania, Przedsiębiorczość i Zarządzanie, Tom XII, Zeszyt 6, Łódź 2011, s. 301.

${ }^{43}$ B. Feldbauer-Durstmüller, H. Pernsteiner, R. Rohatschek, M. Tumpel, , Familienunternehmen, Linde Verlag, Wiedeń 2008, s.57.

${ }^{44}$ A. Winnicka-Popczyk, Finansowanie innowacji w polskich firmach rodzinnych, Wydawnictwo Uniwersytetu Łódzkiego, Łódź 2016, s. 102-109.

${ }^{45}$ A.K. Achleitner i in., op.cit. 2011, s.42.

${ }^{46}$ Ibidem, s. $103-105$.

${ }^{47}$ Ibidem, s. 45 .
} 
Kolejne szerokie badania przeprowadzone zostały przez PricewaterhouseCoopers (PwC) wspólnie z Instytutem Przedsiębiorstw Rodzinnych WHU-Otto Beisheim School of Management. Ich wyniki wskazuja, że przy podejmowaniu decyzji o debiucie giełdowym przez niemieckie przedsiębiorstwa rodzinne cele finansowe (rozumiane jako powodzenie oferty, poziom niedoszacowania ceny emisyjnej, a co z tym związane poziom kursu akcji podczas debiutu) nie są najważniejsze. Bowiem nadrzędnym celem związanym z publiczną emisją akcji jest przede wszystkim minimalizacja ryzyka utraty kontroli oraz wizerunku przedsiębiorstwa. Istotna dla tej grupy podmiotów jest przede wszystkim ochrona tzw. społeczno-emocjonalnego bogactwa (Socialemotional wealth $S E W)$ związanego z firmą. Konsekwencją takiej postawy jest akceptowanie przez przedsiębiorstwa rodzinne wyższego poziomu niedoszacowania ceny $\mathrm{w}$ porównaniu z przedsiębiorstwami nierodzinnymi ${ }^{48}$. Badania PwC wskazują, że w wyniku niedoszacowania przedsiębiorstwa rodzinne podczas IPO rezygnują średnio z $10 \%$ wartości rynkowej emitowanych akcji ${ }^{49}$.

Analiza zagadnień teoretycznych oraz wyników badań prowadzi do konkluzji o niejednoznaczności ocen wpływu obecności na giełdzie przedsiębiorstw rodzinnych na ich wzrost i rozwój. Z jednej strony wskazuje się, że duże rodzinne niemieckie przedsiębiorstwa imponują rozwojem mimo nieobecności na giełdzie papierów wartościowych. Z drugiej strony wyniki badań kończą wnioski o lepszych warunkach do rozwoju dla przedsiębiorstw rodzinnych notowanych na giełdzie. Statystki przytoczone przez Bertholda ${ }^{50}$ wskazują na wyższą dynamikę wzrostu przychodów wśród dużych przedsiębiorstw rodzinnych funkcjonujących poza giełdą niż wśród dużych giełdowych przedsiębiorstw rodzinnych. Jednocześnie z porównywalnych analiz wykonywanych wśród małych i średnich przedsiębiorstw płyną inne wnioski. Mianowicie małe i średnie przedsiębiorstwa rodzinne często charakteryzuje wzrost o wartościach mniej niż przeciętnych. Jednymi $\mathrm{Z}$ istotniejszych przyczyn tego zróżnicowania są restrykcyjne wymogi stawiane małym i średnich przedsiębiorstwom przez potencjalnych kapitałodawców, jak również relatywnie niski poziom finansowania wewnętrznego ${ }^{51}$.

W związku z powyższym, przyjmując wyniki badań przedstawionych przez Bertholda, uprawnione jest przypuszczenie, że korzyści i koszty obecności na giełdzie papierów wartościowych niemieckich przedsiębiorstw rodzinnych zależą od ich wielkości:

- Duże przedsiębiorstwa rodzinne - nie wskazano by nieobecność dużych przedsiębiorstw rodzinnych na giełdzie miała negatywny wpływ na ich finanse, wzrost czy możliwości inwestycyjne.

- Małe przedsiębiorstwa rodzinne - dla nich, ze względu na ograniczone dostęp do kapitału zewnętrznego i obcego - łatwiej dostępny w ostatnich latach - rynek giełdowy jest szansą.

\footnotetext{
48 S. Rau, P. Bartels, IPO-Underpricing in Familienunternehmen, PricewaterhouseCoopers A.G., 2013, www.pwc.de/familienunternehmen, s. 5, 10-11.

${ }^{49}$ Ibidem, s. 5.

${ }^{50}$ F. Berthold, , Familienunternehmen in Spannungsfeld zwischen Wachstum und Finanzierung, Wittener Institut für Familienunternehmen, EUL Verlag, 2010, s. 1-3.

${ }^{51}$ Ibidem, s.3
} 
Niemieckie przedsiębiorstwa rodzinne tworzą znaczącą liczbę debiutantów giełdowych. Wyniki badań z lat 2004-2015 wskazują, że blisko połowę (46\%) IPO stanowiły oferty publiczne przedsiębiorstw rodzinnych. Z kolei średnia wartość emisji przedsiębiorstw rodzinnych wynosiła $65,5 \mathrm{mln}$ euro (mediana 18,2 $\mathrm{mln}$ euro), podczas gdy średnia wartość emisji przedsiębiorstw nierodzinnych to $170,5 \mathrm{mln}$ euro (mediana $34 \mathrm{mln}$ euro). Przeciętna wartość przychodów przedsiębiorstw rodzinnych wprowadzanych do obrotu giełdowego w Niemczech w roku poprzedzających debiut wynosiła 98,3 mln euro, natomiast w przypadku przedsiębiorstw nierodzinnych 454,4 $\mathrm{mln}$ euro ${ }^{52}$. Giełdowe przedsiębiorstw rodzinne są więc mniejszymi podmiotami gospodarczymi niż nierodzinne przedsiębiorstwa notowane na Deutsche B rse (DB).

Zgodnie $\mathrm{z}$ wynikami jedynych - przeprowadzonych $\mathrm{w}$ Niemczech - tak kompleksowych badań dotyczących rodzinnych firm notowanych na giełdzie papierów wartościowych, stanowią one prawie połowę spółek notowanych na DB, a ich wartość rynkowa stanowi jedną trzecią kapitalizacji spółek ujętych w indeksie Composite $\mathrm{DAX}^{53}$.

Ponadto wskazano na następujące cechy giełdowych przedsiębiorstw rodzinnych dotyczące obszaru finansów ${ }^{54}$ :

- Wyższy udział kapitału własnego w strukturze finansowania: w firmach rodzinnych średni udział kapitału własnego wynosił 50\% (mediana 51\%), podczas gdy dla firm nierodzinnych średnia wynosi 36\% (mediana 34\%).

- Średnia wartość sumy bilansowej jest niższa w przypadku firmy rodzinnych niż nierodzinnych.

- Średnia wartość przychodu jest niższa w firmach rodzinnych niż w nierodzinnych.

Mimo, że jak wskazano powyżej przedsiębiorstwa nierodzinne notowane na giełdzie charakteryzuje wyższa wartość sumy bilansowej i przychodów, firmy rodzinne notowane na DB są dużymi przedsiębiorstwami. Dane dotyczące wartości sumy bilansowej, przychodów oraz liczby zatrudnionych osób notowanych przedsiębiorstw rodzinnych wskazują, że średnia wartość sumy bilansowej przedsiębiorstw rodzinnych wynosiła $1180 \mathrm{mln}$ euro, średnia wartość przychodów $1178 \mathrm{mln}$ euro, a średnia liczba zatrudnionych $6112^{55}$.

Na rynku papierów wartościowych istotnym miernikiem informującym o wielkości i pozycji przedsiębiorstwa jest kapitalizacja. Dane wskazują, że w okresie 2000-2008 kapitalizacja przedsiębiorstw rodzinnych stanowiła od 23\% (w roku 2002) do 33-34\% (w latach 2000, 2006) sumy kapitalizacji spółek ujętych w indeksie CDAX ${ }^{56}$. Wśród 30 największych spółek na DB na koniec 2019 znajdowały się trzy przedsiębiorstwa rodzinne s7 $^{57}$

\footnotetext{
${ }^{52}$ Blättchen W., Nespethal U. (2015), Kapitalmarktfinanzierung und Familienunternehmen, FuS nr 5/2015, s. 174.

${ }^{53}$ A.K. Achleitner, i in., Börsennotierte Familienunternehmen in Deutschland, Stiftung Familienunternehmen, Monachium 2010, s. 11.

${ }^{54}$ Ibidem, s.61-63.

${ }^{55}$ Ibidem, s. $62-64$

${ }_{56}^{56}$ A.K. Achleitner i in., op.cit., 2010, s. 44.

${ }^{57}$ www.boerse.ard.de data dostępu 30.05.2019 r.
} 
Na znaczenie przedsiębiorstw rodzinnych na Deutsche Börse oprócz ich liczby i kapitalizacji wskazuje utworzenie specjalnych indeksów giełdowych. Do DAXplus Family Index według danych na koniec maja 2019 roku zakwalifikowanych było 113 przedsiębiorstw (są nie tylko niemieckie, ale również zagraniczne przedsiębiorstwa rodzinne). Natomiast drugi indeks DAXplus Family30 ujmuje 30 największych i najbardziej płynnych przedsiębiorstw rodzinnych i służy jako barometr kondycji małych i średnich przedsiębiorstw rodzinnych ${ }^{58}$.

\section{Zakończenie}

Cechą charakterystyczną wszystkich przedsiębiorstw rodzinnych, w tym niemieckich, jest duży udział kapitału własnego w strukturze finansowania. Kolejnym istotnym według wskazań źródłem finansowania są kredyty i pożyczki. Jednak niemieckie przedsiębiorstwa rodzinne są również silnie reprezentowane na giełdzie papierów wartościowych, mają znaczących udział wśród debiutujących spółek oraz w kapitalizacji giełdy. Co ciekawe przytoczone wyniki badań wśród niemieckich przedsiębiorstw rodzinnych wskazują, że przy podejmowaniu decyzji o debiucie giełdowym kierują się głównie niefinansowymi motywami.

Analizy porównawcze wskazują, że biorąc pod uwagę wartość obrotów i sumę bilansowa, firmy rodzinne obecne na giełdzie są podmiotami mniejszymi niż nierodzinne przedsiębiorstwa giełdowe, ale wciąż klasyfikowane są jako duże przedsiębiorstwa.

Warto podkreślić, że wyniki badań nie wskazują jednoznacznie jak na rozwój przedsiębiorstwa wpływa obecność na giełdzie, ocena korzyści i kosztów zależy m.in. od wielkości przedsiębiorstwa.

\section{Bibliografia}

Achleitner A.K., Kaserer C., Kauf T., Günther N., Ampenberger M., Börsennotierte Familienunternehmen in Deutschland, Stiftung Familienunternehmen, Monachium 2010.

Achleitner A.K., Kaserer C., Günther N., Volk S., Die Kapitalmarktfähigkeit von Familienunternehmen, Unternehmensfinanzierung über Schuldschein, Anleihe und Börsengang, Stiftung Familienunternehmen, Monachium 2011.

Berthold F., Familienunternehmen in Spannungsfeld zwischen Wachstum und Finanzierung, Wittener Institut für Familienunternehmen, EUL Verlag 2010.

Blättchen W., Nespethal U., Kapitalmarktfinanzierung und Familienunternehmen, FuS nr 5/2015.

Czakon W., Metodyka systematycznego przegladu literatury, Przegląd Organizacji $2011 \mathrm{nr} 3$.

Die Volkswirtchaftliche Bedeutung der Familienunternehmen, Stiftung Familienunternehmen, Monachium 2017.

Feldbauer-Durstmüller B. Pernsteiner H., Rohatschek R., Tumpel M., Familienunternehmen, Linde Verlag, Wiedeń 2008.

Gallo M.A., Vilaseca A. Finance in family business, Family Business Review, tom 9, Wiley Online Library 1996.

Gallo M.A., Tapies J., Cappuyns K., Comparison of family and nonfamily business: Financial logic and personal preferences, Family Business Review, nr 17(4) 2004.

\footnotetext{
${ }^{58}$ www.dax-indices.com data dostępu 30.05.2019 r.
} 
Gottschalk S., Niefert M., Licht G., Wagner S.C., Hauer A., Keese D., Woyewode M., Die volkswirtschaftiche Bedeutung der Familienunternehmen, Stiftung Familienunternehmen, Monachium 2014.

Klein, S., Familienunternehmen. Teoretische und empirische Grundlagen, Josef Eul Verlag, Lohmar-Köln 2010.

Małyszek, E. Problem różnorodności definicji i typologii firm rodzinnych - konsekwencje $i$ podejścia do jego rozwiqzania, [w:] Sułkowski Ł. (red.), Firmy rodzinne - współczesne wyzwania przedsiębiorczości rodzinnej. Kierunki i strategie rozwoju. Przedsiębiorczość i Zarządzanie, Tom XIII, Zeszyt 7. Łódź 2012.

Marjański A., Sukcesja jako wyróżnik przedsiębiorstwa rodzinnego, [w:] Sułkowski Ł. (red.), Firmy rodzinne - wspótczesne wyzwania przedsiębiorczości rodzinnej. Kierunki i strategie rozwoju. Przedsiębiorczość i Zarządzanie, Tom XIII, Zeszyt 7. Łódź 2012.

Niemczyk J., Koliński P., WIG Rodzinny na Giełdzie Papierów Wartościowych w Warszawie, [w:] Sułkowski Ł., (red.), Firmy rodzinne - determinanty funkcjonowania i rozwoju. Współczesne aspekty zarzadzania, Przedsiębiorczość i Zarządzanie, Tom XII, Zeszyt 6, Łódź 2011.

Niedbała E. Firmy rodzinne - obiekt badawczy, MBA $2002 \mathrm{nr} 5$.

Pernsteiner H., Węcławski J. (red.), Finansowanie i corporate governance w przedsiębiorstwach rodzinnych, C.H. Beck, Warszawa 2016.

Rau S., Bartels P. , IPO-Underpricing in Familienunternehmen, PricewaterhouseCoopers A.G., 2013 www.pwc.de/familienunternehmen.

Safin K., Przedsiębiorstwo rodzinne, Wydawnictwo Akademii Ekonomicznej IM. Oskara Langego we Wrocławiu, Wrocław 2007.

Smus T.R. Strategie finansowe firm rodzinnych, [w:] Sułkowski Ł., (red.), Firmy rodzinne determinanty funkcjonowania i rozwoju. Współczesne aspekty zarzqdzania, Przedsiębiorczość i Zarządzanie, Tom XII, Zeszyt 6, Łódź 2011.

Stradomski M. , Finansowanie obce firm rodzinnych na rynku niedoskonalym, Polskie Wydawnictwo Ekonomiczne, Warszawa 2010.

Więcek-Janka E., Lewandowska A., Model pięciu poziomów definiowania firm rodzinnych[w:] Sułkowski Ł., Marjański A. (red.), Firmy rodzinne - rozwój teorii i praktyki zarzadzania, Przedsiębiorczość i Zarządzanie, Tom XVIII, Zeszyt 6, część II, Wydawnictwo Społecznej Akademii Nauk, Łódź-Warszawa 2017.

Winnicka-Popczyk A., Finansowanie innowacji w polskich firmach rodzinnych, Wydawnictwo Uniwersytetu Łódzkiego, Łódź 2016.

\section{Summary}

In this article the author focuses on family firms, which are listed on stock exchange. The article presents the importance of family businesses in both the real economy in Germany as well as the activity of the German family businesses on the securities market in terms of the usage of the equity. The aim of the article is to present the most important reasons of IPO and the characteristic of family businesses that are listed on stock exchange. Indeed article shows in the review results of the most important studies of German family businesses that are listed on stock exchange. In the article following methods were used: critical analysis of the literature, as well as components of descriptive statistic and descriptive method. Analysis and the assessment show that family businesses in Germany have a significant impact on the real economy. They are also important issuers on the stock exchange, which is expressed, among others, by the number of both IPOs and listed companies. In comparison to non- family enterprises the family firms listed on stock exchange are characterized by lower balance sheet total and lower turnover. However, the assessment of benefits related to the presence on the stock exchange depends, among the size of the enterprise. 
Keywords: family enterprises, security market, enterprises financing.

Informacje o autorze:

Dr Dominika Kordela

Uniwersytet Szczeciński

Wydział Zarządzania i Ekonomiki Usług

ul. Cukrowa 8

71-004 Szczecin

e-mail: dominika.kordela@wzieu.pl

ORCID: 0000-0002-4826-1352 